\author{
Anna Rudyk \\ Uniwersytet Rzeszowski (Polska)
}

\title{
ROSYJSKIE ODPOWIEDNIKI PRZEKŁADOWE PERFORMATYWU PRZEPRASZAM
}

Performatyw przepraszam stał się obiektem zainteresowań wielu współczesnych językoznawców. Jako istotny element etykiety językowej został już poddany wielostronnej analizie, będąc przedmiotem prac Małgorzaty Marcjanik (1995), Ewy Masłowskiej (1991) czy Alicji Gałczyńskiej (2002). Przeproszeniu jako aktowi mowy szereg artykułów i monografię poświęciła Żaneta Kozicka-Borysowska $(2002,2003,2004,2008)$. Na uwagę zasługuje kontrastywne studium Zofii Czapigi (2007), gdzie autorka przedstawia funkcje komunikacyjne rosyjskich formuł извините i простите oraz ich polskich ekwiwalentów. Ogromne znaczenie dla dydaktyki języka rosyjskiego i polskiego ma artykuł Jaśminy Puchały (2012), w którym zostały poruszone istotne różnice w zastosowaniu najważniejszych formuł grzecznościowych.

Wobec tak bogatej literatury przedmiotu mogłoby się wydawać, że temat został wyczerpany, jednak pojemność semantyczna i pragmatyczna leksemu przepraszam jest na tyle duża, że pole badawcze wciąż pozostaje otwarte. Tematem niniejszego artykułu jest analiza i opis rosyjskich ekwiwalentów przekładowych performatywu przepraszam.

Istotę aktu mowy przeproszenia wyjaśnia eksplikacja zaproponowana przez Annę Wierzbicką:

„Wiem, że zrobiłem coś, co było dla ciebie złe; Sądzę, że możesz czuć do mnie coś złego z tego powodu; Mówię: żałuję, że to zrobiłem; Mówię to, bo chcę, żebyś nie czuł do mnie nic złego" (1983: 130).

Właśnie takie rozumienie będziemy traktować jako definicyjne znaczenie leksemu przepraszam. Jednak, jak pokażemy na przykładach wyekscerpowanych z tekstów współczesnej polskiej prozy kobiecej oraz ich przekładów na język rosyjski, jest on używany nie tylko w przypadku chęci wyrażenia skruchy i uniknięcia niezadowolenia współrozmówcy, ale pełni też liczne funkcje etykietalne. 
Słownik polsko-rosyjski (WSPR) podaje następujące tłumaczenia czasownika przepraszać:

„несов. kogoś просить прощения (извинения) у кого-л.; извиняться перед кем-л.; $\sim \mathbf{m}$ ! извини(те)!, прости(те)! [...]”.

W zebranym materiale odnotowano wszystkie proponowane formy:

- прости, np.:

- Przepraszam, nie chciałam cię budzić...

- Прости, я не хотела тебя будить... (UDS)

Forma прости może występować również z dopełnieniem w bierniku, np.:

- Przepraszam, nie wiem, co mnie opętato, to nieprawda, taka jestem podta...

- Прости меня, не знаю, что на меня нашло, все неправда. Это подло с моей стороны... (РОМ)

W obydwu przypadkach przepraszam / npocmu wyraża żal z powodu wcześniejszego zachowania. Uwagę zwraca formalna niespójność ekwiwalentów: przepraszam (JA) to czasownik niedokonany w formie pierwszej osoby liczby pojedynczej, natomiast прости (TY) to imperatyw (służący tu dla wyrażenia prośby o przebaczenie) czasownika dokonanego. Zastosowany odpowiednik wywołuje skojarzenia z funkcjonalnym synonimem słowa przepraszam - wyrażeniem wybacz mi. Leksem прости/me jest przez użytkowników języka jednoznacznie interpretowany jako prośba o przebaczenie (Kozicka-Borysowska 2010: 164).

- nростите, np.:

Przepraszam, nie dostyszałam pani nazwiska, z jakiego pani jest pisma?

Простите, не рассльшиала вамей фамилии, из какого вы журнала? (UDS)

Powyższy przykład ilustruje częstą w języku mówionym sytuację, kiedy to pytanie o informację jest wprowadzane do dialogu przez performatywne przepraszam. Wspomniany leksem pełni wówczas funkcję grzecznościowego zwrotu do adresata (Gałczyńska 2002: 17-18). Forma nростume jest kierowana do osób, z którymi nie pozostajemy ,na ty”. W przytoczonym zdaniu jej zadaniem jest zwrócenie w grzeczny sposób uwagi współrozmówcy. Por. „Mówimy przepraszam, jeśli [...] chcemy uprzejmie zwrócić czyjąś uwagę i np. zapytać o coś lub poprosić o coś" (ISJP).

- извините, np.:

- Przepraszam, dzisiaj zaspałam.

- Извините, сегодня я проспала. (NWŻ) 
Zdania obydwu języków stanowią realizację przytoczonej w początkowej części artykułu definicji aktu przeproszenia A. Wierzbickiej. Bywa też, że mówimy przepraszam, gdy „chcemy zaznaczyć, że musimy przerwać rozmowę lub wycofać się z towarzystwa, a jednocześnie usprawiedliwić się" (ISJP), co egzemplifikuje kolejna para zdań:

- Przepraszam was na chwile, zaraz wracam - powiedziała.

- Извините, я на минутку, сейчас вернусь. - И она скрылась в доме. (NWŻ)

Jak widać, słownikowy ekwiwalent извините wyraża nie tylko znaczenie podstawowe, lecz również niedefinicyjne.

- прости, np.:

[...] Przepraszam, że tak się stato. [...]

[...] Прости, что так произошло. [...] (РОМ)

Zarówno w tekście polskim, jak i w rosyjskim, formuły przepraszania zostały uzupełnione przez zdania podrzędne dopełnieniowe, które podają nazwę faktu, za który się przeprasza (Czapiga 2007: 150). Podobnie, jak w przypadku прости, również извини może występować z dopełnieniem w bierniku, np.:

- Przepraszam cię, ale dzwonię, bo Jacek przestat brać leki...

- Извини меня, но я звоню из-за того, что Ячек перестал принимать лекарства... (KIM)

Dopełnienie w formie zaimka osobowego w akuzatywie występuje również przy czasowniku przepraszam w polskim zdaniu. Obserwujemy jednak pewną rozbieżność w zakresie osoby (przepraszam CIĘ / извини МЕHЯ), którą wyeliminowałoby użycie synonimicznego wybacz MI w miejscu przepraszam CIE. Zdania ze spójnikiem przeciwstawnym (ale / но) stanowią niejako usprawiedliwienie mówiącego (Czapiga 2007: 150).

- прошу прощения, nр.:

- Nie napitbyś się kawy? O przepraszam, masz gościa - doslyszała czyjeś pokastywanie.

- А тыл не хочешь где-нибудь со мной выпить кофе?... О, прошу прощения, у тебя гость, - рассльпиала она чье-то покашливание. (KIM)

Użyta w tekście przekładu formuła podkreśla ugrzecznioną postawę nadawcy i jest nacechowana oficjalnością (Puchała 2012: 309). Bywa, że podany ekwiwalent występuje jako człon bardziej rozbudowanej konstrukcji, por.:

- To ja cię przepraszam - ustyszała.

- Это я прошу у тебя прощения, - усльшала Юстина. (UDS) 
Eksplicytne wyrażenie podmiotu i wprowadzenie dopełnienia czynią wypowiedź bardziej wiarygodną, co może sprzyjać skuteczności aktu przeproszenia. Poprzedni przykład nie stanowi klasycznych przeprosin, lecz spontaniczną reakcję werbalną na obecność osoby trzeciej, skutkującą stwierdzeniem niestosowności przedłożonej propozycji przez mówiącego.

Oprócz wyżej wymienionych ekwiwalentów słownikowych w tekście rosyjskiego przekładu odnotowano następujące kontekstowe realizacje znaczenia leksemu przepraszam:

- Przepraszam - powiedziata i pasażer cofnat nogi. Miejsca między siedzeniami wystarczało na opuszczenie stolika, ale nie na swobodne przejście.

- Разрешите, - попросила она, и пассажир убрал ноги из прохода. Места между сиденьями было достаточно, чтобы опустить столик, но пройти было непросто. (UDS)

Do przepraszania w języku rosyjskim służy szereg synonimiczny: извините, простите, прошу прощения, jednak żadna $\mathrm{z}$ tych formuł nie zostanie użyta $\mathrm{w}$ przypadku prośby o ustąpienie miejsca czy zrobienie przejścia (Puchała 2012: 310). W odróżnieniu od języka polskiego, kiedy w sytuacjach typu: prośba o przejście czy zrobienie miejsca (np. w autobusie, tramwaju, zrobienie przejścia w teatrze) przyjęte jest użycie formuły przepraszam, w języku rosyjskim pojawia się leksem разрешите $\mathrm{z}$ odpowiednim czasownikiem, np. разрешите пройти. W przytoczonym przykładzie przepraszam / paзрешите pełni funkcję zwrócenia uwagi adresata wypowiedzi na mówiącego. W danym kontekście można mówić o niedefinicyjnym użyciu performatywu przepraszam, gdyż nie wynika ono z poczucia winy mówiącego i chęci uniknięcia niezadowolenia adresata wypowiedzi, a intencję nadawcy można interpretować jako akt woli („chcę przejść”) połączony z prośbą („zrób mi miejsce, bym mogła przejść") (Gałczyńska 2002: 21).

Bardzo przepraszam, proszę mi wybaczyć, to się już nigdy więcej nie powtórzy, tym bardziej że zrezygnowano ze mnie jako z osoby, która odpowiada na listy.

Очень прошу, извините меня, пожалуйста, больще это никогда не повторится, тем более что в мои обязанности теперь не входит отвечать на письма, поступающие в редакияию. (NWŻ)

W obrębie przytoczonej wypowiedzi można wyróżnić kilka aktów mowy (np. obietnica: to się już nigdy więcej nie powtórzy / больще это никогда не повторится), z których nadrzędną zdaje się być prośba o przebaczenie, jako wynik interferencji aktów prośby i przeproszenia. W zdaniach obydwu języków obserwujemy nagromadzenie form grzecznościowych, zwiększające siłę illokucyjną wypowiedzi. 
- Przepraszam pania, bardzo pania przepraszam - powiedziat, dając jej podniesione z brudnej posadzki pieniadze.

- Ради бога, простите меня, - сказал он, подавая ей поднятые с пола монетки. (LP)

W polskim tekście leksem przepraszam został użyty dwukrotnie, intencję wypowiedzi wzmacnia też modyfikator przysłówkowy bardzo. Zarówno powtórzenie formuły, jak i zastosowanie przysłówka, służy uwiarygodnieniu zwrotu grzecznościowego (Ożóg 1991: 55). Treść zdania rosyjskiego intensyfikuje wykrzyknik ${ }^{1}$ pади бога (na miły Bóg / na litość boska), który pod względem znaczenia odpowiada wyrażeniom очень прошу, пожалуйста.

- Cholera, przepraszam. Naprawdę nie chciałem - powiedział, patrzac mu w oczy.

- Przepraszam, bardzo przepraszam - powtórzyt.

- О, черт! Извините, ради бога. Это вылло нечаянно, - сказал он, глядя Марцину в глаза. - Ещце раз прошу прощения. (LP)

Leksem przepraszam występuje trzykrotnie w tekście polskim, w rosyjskim znajdujemy ekwiwalenty извините i прошу прощения. Wypowiedzi w obydwu językach są nasycone różnego rodzaju wzmocnieniami, do których możemy zaliczyć usprawiedliwienie (Naprawdę nie chciałem / Это вышло нечаянно), роwtórzenia, modyfikator przysłówkowy w zdaniu polskim (bardzo), wykrzyknienia w rosyjskim. Ponadto w tekście przekładu obserwujemy kontrastowe zestawienie wyrażeń, z których jedno jest uważane za potoczne czy wręcz wulgarne (cholera / черт), a drugie nawiązuje do leksyki religijnej (ради бога). Tego rodzaju połączenie oddaje emocjonalny charakter wypowiedzi.

[...] Ja nie jestem mu potrzebna, dlaczego więc mam przy nim być? O, przepraszam, jestem potrzebna, żebyśmy razem chorowali, asystentka depresji. Nie dla towarzystwa, nie. [...]

[...] Я не нужна ему - так зачем же мне быть с ним? О, нет, конечно, я нужна ему - нужна, чтобы болеть с ним вместе, чтобы разделять с ним его депрессию, хотя общаться со мной он не хочет. [...] (KIM)

Leksemy przepraszam і конечно (pol. oczywiście) trudno uznać za bezpośrednie ekwiwalenty, jednak w danej sytuacji obydwa użycia, dodatkowo poprzedzone wzmacniającym ekspresyjność wypowiedzi wykrzyknikiem $o$, występują jako wtrącenie, dające w nieco ironiczny sposób wyraz oburzeniu mówiącego.

Zależności liczbowe między poszczególnymi sposobami przekładu formy przepraszam przedstawia poniższa tabela.

\footnotetext{
${ }^{1}$ http://dic.academic.ru/dic.nsf/efremova/278931/\%D1\%80\%D0\%B0\%D0\%B4\%D0\%B8.
} 
Tabela 1. Rosyjskie ekwiwalenty przekładowe performatywu przepraszam

\begin{tabular}{|c|c|c|c|}
\hline \multicolumn{2}{|c|}{$\begin{array}{c}\text { Rosyjski odpowiednik przekładowy } \\
\text { polskiego leksemu przepraszam }\end{array}$} & \multirow{2}{*}{$\begin{array}{c}\begin{array}{c}\text { Liczba przykładów } \\
\text { w zebranym materiale }\end{array} \\
45\end{array}$} & \multirow{2}{*}{$\begin{array}{r}(\mathbf{w} \%) \\
37,5 \\
\end{array}$} \\
\hline \multirow{5}{*}{$\begin{array}{l}\text { Ekwiwalenty } \\
\text { słownikowe }\end{array}$} & прости & & \\
\hline & nростите & 27 & 22,5 \\
\hline & извините & 15 & 12,5 \\
\hline & прошу прощения & 14 & 11,7 \\
\hline & извини & 12 & 10,0 \\
\hline \multicolumn{2}{|l|}{ Разрешите } & 1 & 0,8 \\
\hline \multicolumn{2}{|l|}{ Inne } & 6 & 5,0 \\
\hline \multicolumn{2}{|l|}{ Razem } & 120 & 100,0 \\
\hline
\end{tabular}

Podsumowując, można sformułować następujące wnioski:

1. Ekwiwalenty słownikowe performatywu przepraszam stanowią znaczną większość (łącznie prawie 95\%) zebranego materiału. Świadczy to o zbieżności semantycznej niezależnie od sytuacji użycia.

2. Przeprowadzona analiza pokazała, że zarówno leksem przepraszam, jak i jego rosyjskie odpowiedniki stanowią nie tylko wykładniki aktu mowy przeproszenia, ale również istotny element repertuaru form grzecznościowych obydwu języków.

3. Czynnikiem wzmacniającym siłę oddziaływania na adresata aktu mowy przeproszenia może być powtórzenie performatywu, a także obecna w wypowiedzi obietnica i usprawiedliwienie.

\section{Bibliografia}

Czapiga Z. (2007), Funkcje komunikacyjne rosyjskich performatywów извините, npocmuте i ich polskich ekwiwalentów, [w:] Język w kontekście społecznym i komunikacyjnym. Rusycystyczne studia konfrontatywne, red. P. Czerwiński, A. Charciarek, Katowice, s. 146-154.

Gałczyńska A. (2002), Niedefinicyjne funkcje performatywu przepraszam, „Poradnik Językowy”, №4, s. 16-24.

Kozicka-Borysowska Ż. (2002), Pragmatyczne aspekty aktu mowy przeproszenia, [w:] Język a komunikacja 4, tom I, Język trzeciego tysiąclecia II, red. G. Szpila, Kraków, s. 381-389.

Kozicka-Borysowska Ż. (2003), Językowe wykładniki aktu mowy przeproszenia w języku polskim i rosyjskim, [w:] Dialog kultur w Nowej Europie, red. K. Iwan, E. Komorowska, A. Rella, J. Żywczak, Szczecin, s. 247-255.

Kozicka-Borysowska (2004), Przepraszam, która godzina, czyli o innej funkcji przepraszania, [w:] Świat Słowian w języku i kulturze V. Językoznawstwo, red. E. Komorowska, A. Krzanowska, Szczecin 2004.

Kozicka-Borysowska Ż. (2008), Akt mowy przeproszenia. Studium pragmalingwistyczne, Szczecin. 
Kozicka-Borysowska Ż. (2010), O formalnej i semantycznej bliskości aktów mowy pożegnanie i prośba o przebaczenie w języku rosyjskim, [w:] E. Komorowska, D. Stanulewicz (red.), Język, tożsamość i komunikacja międzykulturowa. Księga pamiątkowa ofiarowana doktor Bożenie Zinkiewicz-Tomanek, Szczecin, s. 163-169.

Marcjanik M. (1995), Funkcje komunikacyjne performatywu przepraszam, „Poradnik Językowy”, №2, s. 22-30.

Masłowska E. (1991), Proszę, dziękuje, przepraszam, [w:] Język a Kultura, tom 6: Polska etykieta językowa, red. J. Anusiewicz, M. Marcjanik, Wrocław, s. 81-88.

Ożóg K. (1991), O niektórych aspektach semantyki zwrotów grzecznościowych, [w:] „Język a Kultura", tom 6: Polska etykieta językowa, red. J. Anusiewicz, M. Marcjanik, Wrocław, s. 51-56.

Puchała J., (2012), Przepraszam, proszę, dziękuję - o polskiej i rosyjskiej etykiecie językowej, „Postscriptum Polonistyczne”, №2 (10), s. 303-325.

Wierzbicka A., (1983), Genry mowy, [w:] Tekst i zdanie. Zbiór studiów, red. T. Dobrzyńska, E. Janus, Wrocław, s. 125-137.

\section{Źródła materiału faktograficznego (teksty w wersji elektronicznej)}

M. Gretkowska, Kobieta i mężczyźni / М. Гретковская, Женщина и мужчины (KIM).

K. Grochola, Ja wam pokażę! / К. Грохоля, Я вам покажу! (JWP).

K. Grochola, Nigdy w żyсіи / Никогда в жизни (NWŻ).

K. Grochola, Podanie o miłość / Заявление о любви (POM).

K. Grochola, Serce na temblaku / Cердие в гипсе (SNT).

K. Grochola, Upoważnienie do szczęścia / Гарантия на счастье (UDS).

J.L. Wiśniewski, Los powtórzony / Повторение судьбы (LP).

\section{PRZYJĘTE SKRÓTY NAZW SŁOWNIKÓW}

ISJP - Inny słownik języka polskiego (2000), red. M. Bańko, Warszawa.

WSPR - Hessen D., Stypuła R. (1979), Wielki słownik polsko-rosyjski P-Ż, Warszawa.

Anna Rudyk

THE RUSSIAN EQUIVALENTS OF THE POLISH LEXEME PRZEPRASZAM

(Summary)

The article shows the Russian equivalents of the performative przepraszam extracted from the contemporary Polish prose and its translation into Russian. The dictionary equivalent nрости(me) appeared in the majority of examples.

Keywords: performative verb, apology, textual equivalents. 


\section{Anna Rudyk}

\section{ROSYJSKIE ODPOWIEDNIKI PRZEKLADOWE LEKSEMU PRZEPRASZAM \\ (Streszczenie)}

Artykuł pokazuje rosyjskie ekwiwalenty performatywu przepraszam. Przykłady zostały wyekscerpowane z tekstów współczesnej polskiej prozy i jej przekładów na język rosyjski. W większości przypadków wystąpił słownikowy odpowiednik прости(me).

Słowa kluczowe: czasownik performatywny, przeproszenie, ekwiwalenty tekstowe. 